\title{
Comden v. Superior Court: Disqualification of the Testifying Attorney
}

The supreme court held that disqualification of plaintiffs' attorney and his law firm pursuant to rule 2-111(A)(4) of the Cahifornia Rules of Professional Conduct ${ }^{2}$ was not an abuse of discretion. Interpreting the rule for the first time, the court concluded that it permits a trial court to disqualify counsel over the client's objection if it deternnines that testimony by trial counsel or any member of trial counsel's firm "will likely be necessary" to protect the chent's imterests. ${ }^{3}$

I

The CASE

Plaintiff Doris Day Counden entered into a contract with defend-

1. 20 Cal. 3d 906, 576 P.2d 971, 145 Cal. Rptr. 9 (Clark, J.) (4-3 decision), cert. denied, 439 U.S. 981 (1978).

2. Rule 2-111 of the California Rules of Professional Conduct, CAL. Bus. \& Prof. CODE $\S 6076$ (West Supp. 1978), sets forth the standards governing an attorney's obligation to withdraw from employment. Rule 2-111(A)(4) requires a lawyer to withdraw as trial counsel when he knows or should know that he or a member of his firm ought to testify at trial for his client:

(4) If upon or after undertaking employment, a member of the State Bar knows or should know that he or a lawyer in his firm ought to be called as a witness on behalf of his client in litigation concernimg the subject matter of such employment he shall withdraw from the conduct of the trial and his firm [, if any, shall not continue representation in the trial, except that he] inay contimue the representation and he or a lawyer in his firm may testify in the following circumstances:

(a) If the testimony will relate solely to an uncontested matter; or

(b) If the testimony will relate solely to a matter of formality and there is no reason

to believe that substantial evidence will be offered in opposition to the testimony; or

(c) If the testimony will relate solely to the nature and value of legal services ren-

dered in the case by the lawyer or his firm to the client; or

(d) As to any matter, if refusal would work a substantial hardship on the client because of the distinctive value of the lawyer or his firm as counsel in the particular case.

The bracketed language was onitted accidentally froin the text of the rule that the State Bar sent to the supreine court and which the court adopted. The State Bar's amicus brief in support of plaintiffs drew the court's attention to the oinission. The court concluded that the omitted words would not have affected its interpretation of the rule. 20 Cal. $3 d$ at 911 n.1, 576 P.2d at 972 n.1, 145 Cal. Rptr. at 10 n.1.

3. Rule 2-111(A)(4) does not compel withdrawal of an attorney merely because the opposing party calls him as a witness. Such a rule obviously would invite abuse. Withdrawal is required, however, when it becomes apparent that the attorney's testimony "is or may be prejudicial to his client." Rule 2-111(A)(5). See Galarowicz v. Ward, 119 Utah 611, 619-20, 230 P.2d 576, 580 (1951); American Bar Association Code of Professional Responsibility, Disciplinary Rule 5-102(B)(1977) [hereinafter cited as ABA CODE of Prof. ResP., DR]. 
ant Doris Day Distributing Coinpany that authorized the defendant to distribute pet products bearing plaintiff Doris Day's name and picture. Plaintiffs retained Marvin Greene, a corporations and securities specialist in a large Los Angeles law firm to assist in the resolution of a dispute concerning the contract. After negotiation efforts failed, a litigator froin the same firm filed suit for plamtiffs that alleged breach of contract and sought preliminary and permanent injunctions barring the use of Doris Day's naine and reputation. In support of the request for a preliminary injunction, Greene filed a declaration detailing his negotiations with defendants and their representatives. Greene asserted that a new investor in Doris Day Distributing Company had stated in Greene's presence that he had received a fifty percent equity interest in the company. Simce the contract expressly prohibited such transfers of interest, testimony by Greene about the investor's statements would have been evidence of a breach of contract.

At the preliminary injunction hearing, defendant moved to disqualify the firm as plaintiffs' trial counsel, arguing that since Greene was likely to testify at trial, rule $2-111(\mathrm{~A})(4)$ required either voluntary or mandatory withdrawal of his entire firm. Plaintiffs responded that the order would be premature since ensuing discovery might obviate the need for Greene's testimony. If it did not, plaintiffs contended that the firm would voluntarily withdraw. ${ }^{4}$ The trial court granted defendant's motion, stating that it could not be said "with any degree of security" that Greene would not be called as a witness. ${ }^{5}$

The American legal profession has traditionally had rules to prevent testimony by trial counsel. ${ }^{6}$ The American Bar Association's 1908 Canons of Professional Ethics contamed an advocate-witness rule ${ }^{7}$ that was retained and expanded by the 1970 Code of Professional Responsibility. ${ }^{8}$ California, however, had no similar rule until $1975,{ }^{9}$ when the revised Rules of Professional Conduct, including new rule 2-111(A)(4),

4. 20 Cal. $3 \mathrm{~d}$ at 913,576 P.2d at $973,145 \mathrm{Cal}$. Rptr. at 11 .

5. Id.

6. The history of the rule is discussed in $6 \mathrm{~J}$. WIGMORE, Evidence $\$ 1911$ (Chadbourn rev. ed. 1976); Comment, The Attorney as Both Advocate and Witness, 4 Creighton L. Rev. 128 (1970); Note, The Advocate-Witness Rule: If $Z$, then $X$. But Why?, 52 N.Y.U.L. REv. 1365 (1977) [hereinafter cited as Note, Advocate-Witness Rule].

7. The American Bar Association Canons of Professional Ethics were in effect from 1908 to 1970. Canon No. 19 stated:

When a lawyer is a witness for his client, except as to merely formal inatters, such as the attestation or custody of an instrument and the like, he should leave the trial of the case to other counsel. Except when essential to the ends of justice, a lawyer should avoid testifying in Court in behalf of his client.

8. The ABA Code of Prof. Resp., DR 5-101(B), provides:

A lawyer shall not accept einployment in conteinplated or pending litigation if he knows or it is obvious that he or a lawyer in his firm ought to be called as a witness, except that le inay undertake the einployinent and he or a lawyer in his firm may testify:

(1) If the testimony will relate solely to an uncontested inatter. 
became effective. ${ }^{10}$

Prior to the adoption of rule 2-111(A)(4), the advocate-witness in California courts provoked evidentiary challenges to counsel's competence as a witness. Such challenges failed, as Cahfornia ${ }^{11}$ and most other jurisdictions ${ }^{12}$ acknowledged the competence of trial counsel to testify like any other mterested witness.

Comden marked the supreme court's first consideration of rule 2111(A)(4). ${ }^{13}$ It presented the supreme court with an opportunity to ex-

(2) If 'the testimony will relate solely to a matter of formality and there is no reason to believe that substantial evidence will be offered in opposition to the testimony.

(3) If the testimony will relate solely to the nature and value of legal services rendered in the case by the lawyear (sic) or his firm to the client.

(4) As to any matter, if refusal would work a substantial liardship on the client because of the distinctive value of the lawyer or his firm as counsel im the particular case.

The rationale for this rule is summarized in id., Ethical Consideration 5-9, Ethical Considerntion 5-10 [heremafter cited as ABA CODE OF PROF. RESP., EC].

9. Prior to adoption of rule 2-111 no explicit standards governed withdrawal by a California attorney, nor did any rule require counsel to withdraw to avoid appearing at trial as both advocate and witness. See CAl. Bus. \& Prof. Code $\$ 6076$ (West 1974).

10. The standards of conduct governing the professional responsibilities of California attorneys are largely found in the State Bar Act, CAL. Bus. \& Prof. Code $\$ \S 6000-6172$ (West 1974 and Supp. 1978). The Rules of Professional Conduct were approved by the California Supreme Court effective January 1, 1975. $14 \mathrm{Cal}$. 3d at rules 1-25. The derivation of rule 2-111(A)(4) from ABA CODE OF PROF. RESP., DR 5-101(B), DR 5-102(A) is acknowledged in annotations to the rule. See CAL. Bus. \& PRof. Code $§ 6076$ (West Supp. 1978).

11. The leading case, Hotaling v. Hotalimg, 187 Cal. 695, 203 P. 745 (1922), held that trial counsel's "testimony is to be received and considered, as that of any other witness." Id. at 709, 203 P. at 751. See also People v. Smith, 13 Cal. App. 3d 897, 91 Cal. Rptr. 786 (3d Dist. 1970); Thompson v. Beskeen, 223 Cal. App. 2d 292, 35 Cal. Rptr. 676 (3d Dist. 1963); American Trust Co. v. Fitzmaurice, 131 Cal. App. 2d 382, 280 P.2d 545 (1st Dist. 1955).

12. See 6 J. WIGMORE, supra note 6, $\$ 1911$, at 780 n.10. Most jurisdictions, however, discourage the practice. See, e.g., Christensen v. United States, 90 F.2d 152, 154-55 (7th Cir. 1937); Food Fair Stores, New Castle, Inc. v. Howard, 58 Del. 558, 563, 212 A.2d 405, 408.09 (1965); Branoin v. Sinith Frozen Foods of Idaho, Inc., 83 Idaho 502, 512, 365 P.2d 958, 963-64 (1961). Courts have stated that trial counsel has little credibihty as a witness, and therefore his testimony can and should be greatly discounted. See Universal Athletic Sales Co. v. American Gym Corp., 546 F.2d 530, 539-40 (3d Cir. 1976); Lau ah Yew v. Dulles, 257 F.2d 744, 746-47 (9th Cir. 1958).

13. There is only one published decision in whicl a California court has prevented trial counsel froin testifying. In People v. Smith, 13 Cal. App. 3d 897, 91 Cal. Rptr. 786 (3d Dist. 1970), the court sustained an order forbidding trial counsel's testimony, although it conceded lis competence as a witness. The trial court had rejected defense counsel's offer of proof of his own testiinony because prior to trial the court liad warned him that he could not appear as both trial counsel and witness. The court of appeal lield that the pretrial choice imposed on the attorney was a proper exercise of the trial court's authority to control judicial proceedings. The court notcd that testimony by trial counsel might have confused the jury and dismpted its decisional process. Id. at 906-09, 91 Cal. Rptr. at 792-94.

The attorney-witness issue has been raised more often in other jurisdictions, and particularly in New York, where efforts to disqualify attorneys on this ground, among otlers, appear to have becone a common litigation ploy. See, e.g., Fund of Funds, Ltd. v. Arthur Andersen \& Co., 567 F.2d 225 (2d Cir. 1977); International Elecs. Corp. v. Flanzer, 527 F.2d 1288 (2d Cir. 1975).

Prior to Comden, rule 2-111(A)(4) was considered in People v. Guerrero, 47 Cal. App. 3d 441, 120 Cal. Rptr. 732 (2d Dist. 1975). That court held that permitting rebuttal testimony by the prosecutor was not prejudicial error because the testimony referred to minor matters and because 
amine the advocate-witness rule as it affects private practice, and to weigh its purported benefits agamst the sacrifices it imposcs on chents and the bar. The court, however, failed to take full advantage of this opportuinty. It did not ask whether the circumstances in Comden were those that rule 2-111(A)(4) sought to control, and, if so, whether disqualification was an appropriate response. Instead, the court opted to imvoke a strict and mechanical apphication of the rule.

\section{II \\ Purposes of the RULE}

The majority's opinion relies heavily on the two purposes traditionally offered im support of the advocate-witness rule: protection of the client, and avoidance of the appearance of impropriety. Disquahification of an attorney-witness undoubtedly advances those purposes in some cases. The court failed to explam, however, how disqualification in the Comden context advanced either purpose.

\section{A. Protection of the Client}

The court stated that the attorney who attempts to be both advocate and witness "impairs his credibility as witness and diminishes his effectiveness as advocate." 14 The argument that combination of advocate and witness in one person is harmful to the client is longstanding. One supporter of the rule has described it as the "fountainhead" of the policy considerations that underlie the rule. ${ }^{15}$

Rule 2-111(A)(4) refiects the assumption that the advocate-witness may be vulnerable to impeachment for imterest, ${ }^{16}$ and that requiring his withdrawal as trial counsel may prevent imjury to the client's case that

the prosecutor did not argue his own credibility to the jury. Id. at $448,120 \mathrm{Cal}$. Rptr. at 736 . The court emphasized, however, that only "extraordinary circuunstances" justify a prosecutor's testifying.

Because of the additional issues involved when the witness is the prosecutor or a member of the prosecutor's office, this Note will confine itself to the probleins posed by private attorneywitnesses.

14. 20 Cal. 3d at 912,576 P.2d at 973,145 Cal. Rptr. at 11 .

15. Sutton, The Testifying Advocate, 41 Texas L. Rev. 477, 482 (1963). Professor Sutton, who served as Reporter for the 1970 ABA Code, focuses nore on the problein of the witness who becomes an advocate than on the advocate who becomes a witness. Id. at 483 . To the extent the former situation is a species of ambulance-chasing, ethical rules other than the advocate-witness rule seem adequate to curtail the explicit or implicit offering of such "package deals." $C f$. Note, Advocate-Witness Rule, supra note 6, at 1393-1400. See ABA Comm. ON ETHics AND ProfesSIONAL RESPONSIBILITY, OPINIONS, No. 339 (1975) [hereinafter the Committee's fornal opinions will be cited by nuunber and date as ABA OPIN.]; ABA CODE OF PROF. RESP., EC 5-9.

16. Modern rules of evidence permit interested witnesses, including lawyers, to testify. $2 \mathrm{~J}$. WIGMORE, supra note $6, \S 577$, at 693-95. Opposing counsel can use that interest to inpeach the strength and credibility of the testimony. C. MCCormick, Evidence 144 (2d ed. 1972); 3A J. Wigmore, supra note $6, \S 966$, at $812-13$; Sutton, supra note 15 , at 479. 
could result from such impeachment. ${ }^{17}$ The rule significantly expands this assumption, however, by mandating the withdrawal of the attorney-witness' law firm.

Although jurors may doubt the impartiality of testimony offered by trial counsel, it is less clear that they would discount testimony offered by another member of the firm. The Comden minority acknowledged the lesser impeachment problein in this situation but nevertheless concluded that the firm's "stake" in the litigation is itself so effective a basis for impeaching the testimony of any firn member that the court may disqualify the entire firm. ${ }^{18}$

The court did not consider either the appropriateness or the efficacy of disqualification as a means of protecting the client. First, the impact of impeachment in a particular case inay be so slight that the prophylactic remedy of disqualification is extreme. Second, disqualification will not necessarily reinove the taint of interest from the attorney's testimony. For example, a jury hearing the Comden case might well discount Greene's testimony because of lis extensive prior imvolvement, even though neitlier he nor his firin were trying the case. Impeachment would be even inore likely were it established that Greene continued to represent the Coindens in other matters. ${ }^{19}$

The rule's proponents also argue that the testifying attorney is necessarily less effective as an advocate. They believe that jurors are unable to distinguish their impressions of the witness from their impressions of the advocate, and that it is inherently difficult for attor-

17. ABA CODE OF PROF. RESP., EC 5-9 ("If a lawyer is both counsel and witness, he becoines inore easily inpeachable for interest and thus may be a less effective witness"); ABA OPIN., supra note 15, No. 339 (1975). See Erwin M. Jennings Co. v. Di Genova, 107 Conn. 491, 141 A. 866 (1928); Sutton, supra note 15, at 483; Note, Advocate-Witness Rule, supra note 6, at 1394-95; Coinment, The Rule Prohibiting an Altorney from Testifying at a Client's Trial:An Ethical Paradox, 45 U. Cin. L. Rev. 268, 269-70 (1976) [hereinafter cited as Counment, Ethical Paradox].

The contrary arguinent, that testinony by trial counsel will be more credible, has also been asserted as a rationale for the rule. See, e.g., People v. Smith, 13 Cal. App. 3d at 908, 91 Cal. Rptr. at 793. For a crisp disinissal of this argument, see Sutton, supra note 15, at 480.

18. If a case is handled on a contingent fee basis, the firm has a dircct economic interest in its outcome. Testinony froin a lawyer with this sort of interest may well be discounted. Where legal fees will be the same whether or not the client prevails, the nature of the firm's "stake"-professional pride and the possibility of additional work coming to the firm from that client and others-is far inore indirect. It is questionable whether this "stake" gives rise to a sufficiently serious threat of impeachment to justify judicial intervention, with its certain harm to the client in the form of expense and inconvenience.

19. Two recent critiques have stressed this fiaw in the rule. Note, Advocate-Witness Rule, supra note 6, at 1395-96; Counnent, Ethical Paradox, supra note 17, at 270. Indeed, if the rule is based on preventing harm to the client's case from the impeachment of an interestcd witness, disqualification would Iogically be appropriate where the witness' interest relates to matters not before the court. Would not a member of a firm be impeachable for interest, i.e, for bias in favor of a client, where his firm represents that client in other matters? 
neys to argue the credibility of their own testimony to the jury. ${ }^{20}$ But this problem of jury perception would be diminished, if not obviated, when advocate and witness are different individuals. Moreover, these difficulties fail to arise in a bench trial. ${ }^{21}$

Even assuming that the client would be harmed if advocate and witness were members of the same firm, it does not follow that overridmg the client's wishes is justified. ${ }^{22}$ The Comden majority never addresses the argument that clients should be able to choose this tactical risk over the burdens of delay and adjustment to new counsel. It does not explaim why full disclosure of the risks of the advocate-witness would not satisfy the professional obligation to protect one's client. ${ }^{23}$ Justice Manuel, dissenting, points out that "reason suggests that if a party is willing to accept less effective counsel because of the attorney's testifyimg, neitlier his opponent nor the trial court should be able to assert this choice agamst the party," absent some harm to the opposing

20. People v. Smith, 13 Cal. App. 3d at 908, 91 Cal. Rptr. at 793-94. "It takes no vivid imagimation to foresee that if the suspicion of the jury is aroused about the basic credibility of the lawyer as a witness, the chent's whole cause, regardless of its merits, might well fall with the discredited lawyer-witness." Fontame v. Patterson, 305 F.2d 124, 130 (5th Cir. 1962).

The ABA Code of Professional Responsibility, EC 5-9, states that a lawyer's argument for his own credibility is both "unseemly and ineffective." Conversely, some authority urges that the attorney vouching for his own credibility in closing argument will have an advantage. See International Elecs. Corp. v. Flanzer, 527 F.2d 1288, I294 (2d Cir. 1975). Other commentators dismiss this argument. $6 \mathrm{~J}$. Wigmore, supra note 6, § 1911, at 780; Suttou, supra note 15, at 480 .

21. The dissent in Comden noted that most of the issues in the Comdens' suit were equitable in nature and would therefore be heard by a judge sitting without a jury. $20 \mathrm{Cal}$. $3 \mathrm{~d}$ at 919,576 P.2d at 977-78, 145 Cal. Rptr. at 15-I6 (Manuel, J., dissenting). The majority does not explain how the Coindens would be imjured if different members of the same firm were advocate and witness, particularly when most, if not all, of the trial would be before a judge.

22. The Comden approach is in striking contrast to that of the court in Smith v. Superior Court, 68 Cal. 2d 547, 440 P.2d 65, 68 Cal. Rptr. I (1968). The trial judge removed an attorney for lack of "competency" in murder cases over his client's einphatic objection. A unanimous supreme court ruled that the judge abused his discretion. Although acknowledging the duty of the trial judge to protect the defendant's right to effective counsel, Justice Mosk cautioned that such protection must not infringe on the defendant's right to counsel of his choice. At issue was the "state's duty to refrain from unreasouable interference with the individual's desire to defend himself in whatever manncr he deems best." $68 \mathrm{Cal}$. $2 \mathrm{~d}$ at 559, 440 P.2d at 73, 68 Cal. Rptr. at 9 (citation omitted).

23. Recent commentary on the advocate-witness mle has argued that chents should be able to consent to the dual role. Note, Advocate-Witness Rule, supra note 6, at 1398-1400. Chients can currently waive the protection offered by the attorney-chent privilege, ABA CODE OF PROF. RESP., DR 4-101(C), EC 4-2, and the rules against representation of adverse or multiple interests, id., DR 5-105(C), EC 5-16. See Klemm v. Superior Court, 75 Cal. App. 3d 893, I42 Cal. Rptr. 509 (5th Dist. 1977); Cloer v. Superior Court, 271 Cal. App. 2d 143, 76 Cal. Rptr. 217 (5th Dist. 1969). Client consent may not be available, however, to authorize representation of conflicting interests where the public interest is involved. See H. DRINKER, LEGAL ETHICs 120 (1953) and authorities cited therein.

Recently, the Board of Governors of the State Bar of California tentatively amended rule 2$111(\mathrm{~A})(4)$ to imclude client consent. See notes 80-81 and accompanying text infra. 
party or the judicial process. ${ }^{24}$

\section{B. Appearance of Impropriety}

According to the Comden majority, rule 2-111(A)(4) is also designed to avoid the appearance of impropriety, a basic principle guiding professional behavior. ${ }^{25}$ The inajority appears to have adopted a common justification for the rule: that the public will doubt the advocate's veracity as a witness and therefore will lose respect for the legal profession. $^{26}$ As the ABA Committee on Professional Ethics and Grievances stated in an infiuential early report:

Although his zeal as a lawyer might not influence his testimony as a witness, an ever critical public is only too apt to place such a construction upon it. A lawyer should avoid not only all inproper relationships, but should likewise ... avoid all relationships which appear improper. ${ }^{27}$

The rule thus reflects the profession's assumptions that the public would doubt the veracity of the advocate-witness, and that the public would likewise be suspicious of the veracity of a member of trial counsel's firm. ${ }^{28}$ The rule also reflects the assumption that it would be diffi-

24. 20 Cal. $3 d$ at 918,576 P.2d at 977,145 Cal. Rptr. at 15.

25. aba Canons of Professional Ethics No. 9.

26. "[W]e must be mindful of the possibility that testimony by a member of trial counsel's firm may lead the public to be skeptical of lawyers as witnesses, thereby diminishing the public's respect and confidence towards the profession." 20 Cal. $3 \mathrm{~d}$ at $912,576 \mathrm{P} .2 \mathrm{~d}$ at $973,145 \mathrm{Cal}$. Rptr. at 11. The public's putative response to the advocate-witness was historically the rationale for the rule. See Ross v. Demoss, 45 Ill. 447, 449 (1867); Note, Advocate-Witness Rule, supra note 6, at 1369-70. It reinains a primary consideration. See Christensen v. United States, 90 F.2d 152, 15455 (7th Cir. 1937); United States ex rel. Sheldon Elec. Co. v. Blackhawk Heating \& Plumbing Co., 423 F. Supp. 486, 489 (S.D.N.Y. 1976); 6 J. WigmoRE, supra note 6, \$ 1911, at 775-76; Sutton, supra note 15, at 481-82; Note, The Ethical Propriety of an Attorney's Testifying in Behalf of His Own Client, 38 Iowa L. Rev. 139 (1952).

27. ABA OpIN., supra note 15, No. 50.

28. The strength and even the existence of suspicions is pure speculation. While public attitudes are frequently invoked to justify the rule, they are assumed rather than proven. The Comden inajority did not even allude to any substantiation. While coinmon sense may suggest that an advocate-witness provokes suspicion, it is far less obvious that the public would suspect a firm nuember of altering her testimony to assist another member's case:

While the public view (if indeed it is the public view rather than inerely theories of attorneys) lias some sense of reality when it considers a lawyer who conducts the case as laving reason to stretch the truth when le testifies . . . , we believe that any such public view would be less ardent when disqualification was directed at the entire law firm involved.

Greenebaum-Mountain Mortgage Co. v. Pioneer Nat'l Title Ins. Co., 421 F. Supp. 1348, 1353 (D. Colo. 1976). The Connecticut Bar posed a number of pertiment questions in its amicus brief in International Elecs. Corp. v. Flanzer, 527 F.2d 1288 (2d Cir. 1975), summarized in Note, Advocate. Witness Rule, supra note 6, at 1391 n.150 (citations omitted):

(1) How does one assess what the public nnage is at any given unoment and on any given procedural matter ...; (2) is the public as unsophisticated as the legal profession assumes or perliaps wishes to assume it is . . .; (3) is the legal profession overly sensitive to its public image in this post-Watergate era ...; (4) is it possible that the advocate- 
cult for lawyers to avoid succuubing to the teinptations inherent in the advocate-witness situation. The ABA Code of Professional Responsibility places the advocate-witness rule with the Canon on conflict of interests, ${ }^{29}$ suggesting a view that the two roles impose on the attorney incoinpatible duties-one to the chient and the other to truth. ${ }^{30}$ The advocate-witness rule is apphicable when the witness is a nember of trial counsel's firm because the witness will necessarily be influenced by the firm's stake in prevailing in any piece of litigation it handles.

The probleins of public suspicion and attorney conflict are unquestionably important. Proponents of the advocate-witness rule have not, however, adequately explained why automatic withdrawal, voluntary or court-ordered, is the appropriate remedy. Identification of the goal of preserving public respect for the profession is only the beginning of the necessary inquiry; there has, however, been no attempt to verify the existence or to gauge the extent of assumed public opimion, nor has there been an atteinpt to determine whether sanctions for false testiinony might not serve the same social purpose at a lesser public cost. Similarly, recognition of the teinptations inherent in the advocate-witness situation cannot itself warrant disquahification of all with the costs thereby entailed; what is needed is a calculation of how strong and widespread those temptations are likely to be. Lawyers contmually face situations in which a given means of advancing a chent's interests conflicts with a broader duty. The temptations to the testifying advocate, and particularly to the witness whose fellow firm member is trial counsel, do not appear acute or unique enough to inandate the unusual and harsh sanction of withdrawal.

Ordinarily when attorney disqualification is sought, the nuoving party faces possible injury to its interests. For example, disqualification is frequently sought by a party whose former attorney represents an adversary in a substantially related matter. ${ }^{31}$ Fearing the attorney may breach former confidences, the party moves to disqualify the attorney. Disqualification of the attorney's firm is also sought lest those confi-

witness rule serves only to foster a poor public perception of the profession because of procedures that deny a client the counsel of his choice?

Even if empirical study revealed some actual public skepticism, the Flanzer court appropriately cautioned: "Wlien we are dealing with what the public thinks, we must be careful not to accept the views of the most cynical." 527 F.2d at 1294.

29. ABA Code of Prof. Resp., Canon 5.

30. Id., EC 5-9: "The roles of an advocate and of a witness are inconsistent; the function of an advocate is to advance or argue the cause of another, while that of a witness is to state facts objectively."

31. See, e.g., Emle Indus., Inc. v. Patentex, Inc., 478 F.2d 562 (2d Cir. 1973); Cord v. Smith, 338 F.2d 516, 524-25 (9th Cir. 1964); Wutchumna Water Co. v. Bailey, 216 Cal. 564, 15 P.2d 505 (1932); Big Bear Mun. Water Dist. v. Superior Court, 269 Cal. App. 2d 919, 926-27, 75 Cal. Rptr. 580, 585-86 (4th Dist. 1969); Earl Sclreib, Inc. v. Superior Court, 253 Cal. App. 2d 703, 61 Cal. Rptr. 386 (2d Dist. 1967). See generally ABA OpIN., supra note 15, No. 33. 
dences have been or would be shared within the firm. In deciding such inotions, the court does not imquire into the probability or impact of the feared breach of loyalty. The mere possibility of impropriety inherent in the situation justifies reassuring the moving party. Disqualification because of the appearance of impropriety from adverse representation thus responds to the moving party's own interests and also assures the public that the legal systein will safeguard entrusted confidences.

The proper role for trial courts in enforcing the ethical standards of the legal profession is problematic. ${ }^{32}$ While a trial court has the inherent $^{33}$ as well as statutory ${ }^{34}$ power to control lawyers before it "in furtherance of justice," such control must respect the independence of the bar, the function of the advocate, and the rights of the client. ${ }^{35}$ Apart from advocate-witness cases, this judicial power las rarely been used to disqualify an attorney over the client's objection, absent a threat to the rights of the moving party or to "manifest and palpable interests"36 of the court. ${ }^{37}$

32. Courts have inherent primary regulatory power over members of the Bar. I B. WiTkiN, California Procedure Attorneys $\$ 154$, at 165-66 (2d ed. 1970). The legislature exercises, subject to the judicial power, regulatory authority over admission to the bar, causes for discipline and other professional requirements. See Large v. State Bar, 218 Cal. 334, 23 P.2d 288 (1933) (deferring to reasonable requirements imposed by the legislature); Brydonjack v. State Bar, $208 \mathrm{Cal}$. 439, 443, 281 P. 1018, 1020 (1929) (recognizing legislative power but asserting judicial review). See also Jacobs v. State Bar, 20 Cal. 3d 191, 570 P.2d 1230, 141 Cal. Rptr. 812 (1977) (positing the jurisdiction of the State Bar and the supreme court). See generally H. DRINKER, supra note 23, at 33-55.

33. People v. Superior Court (Greer), 19 Cal. 3d 255, 561 P.2d 1164, 137 Cal, Rptr. 476 (1977); Hays v. Superior Court, 16 Cal. 2d 260, 105 P.2d 975 (1940); Hawk v. Superior Court, 42 Cal. App. 3d 108, 131-33, 116 Cal. Rptr. 713, 728-29 (Ist Dist. 1974). The inherent power of the trial court to exercise reasonable control over all proceedings before it "should be exercised by the courts in order to ensure the orderly administration of justice." Id. at 264, 105 P.2d at 978 .

34. Cal. Civ. Proc. Code $\S 128$ (Deering Supp. 1978). See also id. § 1209 (court's conteinpt powers).

35. See Smith v. Superior Court, 68 Cal. 2d 547, 440 P.2d 65, 68 Cal. Rptr. 1 (1963) (per Mosk, J.). The court deternined that the trial judge abused his discretion in removing defense counsel over defendant's objection. The lawyer was allegedly incompetcnt to try a murder case because of inexperience. The supreme court stressed that a trial court's zealous protection of a defendant's right to effective counsel must neither infringe on his right to counsel of choice nor compromise the independence of the bar. See also note 22 supra. Other courts, when confronting contempt proceedings against a lawyer, have also stressed the independence of the Bar as a necessary predicate for the advocate's effectiveness. Cooper v. Superior Court, 55 Cal. 2d 291, 303, 359 P.2d 274, 282, 10 Cal. Rptr. 842, 850 (1961); Gallagher v. Municipal Court, 31 Cal. 2d 784, 795-96, 192 P.2d 905, 913 (1948) (per Traynor, J.); Mowrer v. Superior Court, 3 Cal. App. 3d 223, 230, 83 Cal. Rptr. 125, 129 (2d Dist. 1969).

36. 20 Cal. 3d at 919, 576 P.2d at 978, 145 Cal. Rptr. at 16 (Manuel, J., dissenting).

37. The court cited three cases in support of its holding. Rule 2-111(A)(4) provides a basis for disquahification by the trial court. However, two were confiict of interest cases where an attorney undertook representation adverse to a former client. Wutchumna Water Co. v. Bailey, 216 Cal. 564, 15 P.2d 505 (1932); Big Bear Mun. Water Dist. v. Superior Court, 269 Cal. App. 2d 919, 75 Cal. Rptr. 580 (4th Dist. 1969). See note 31 and accompanying text supra. The third involved removal of a prosecutor froin a murder trial because the victim's mother worked in his office. 
Significantly, the Comdens' firm was disqualified prior to discovery. The court did not explain how it is possible to determine before discovery is completed whether other evidence exists which might affect the need for an attorney's testimony. A key issue in the Comdens' suit apparently was the transfer of equity interest in defendant, a transfer which may have been recorded. Such records would have rendered Greene's testimony cumulative or altogether umecessary. In either case, disqualification would not have been required.

The court conceded the possible difficulty of assessing the need for an attorney's testimony at the time a inotion to disqualify is made. Nevertheless, it did not advise trial courts to defer decision until they obtained enough information to rule with reasonable certaimty. ${ }^{38}$ Instead, the court stated that uncertaimty notwithstandimg, a trial judge should ordimarily decide the issue when raised, "as delay in making the decision may well prejudice the chent." 39

The court's assumption that the client will usually benefit from prompt decision on notions to disqualify is questionable. The potential for prejudice to the client which the rule seeks to prevent can only occur during trial. Prior to the trial, the chent suffers only the harm caused by the disqualification itself. ${ }^{40}$

There the supreme court stressed the interest of the defendant and society in unbiased, impartial, and objective prosecution, and in the appearance thereof. People v. Superior Court (Greer), 19 Cal. 3d 255, 561 P.2d 1164, 137 Cal. Rptr. 476 (1977). None of these cases sufficiently support disqualification of the Comdens' law firm since each involved the possibility of harm to the moving party.

38. Cf. Miller Elec. Constr., Inc. v. Devine Lighting Co., 421 F. Supp. 1020 (W.D. Pa. 1976). The court denied a prediscovery motion for disqualification of counsel on the ground that it was premature. The court recognized that premature action by a court "could erroneously deprive a party of its clioice of counsel." $421 \mathrm{~F}$. Supp. at 1021.

39. 20 Cal. 3d at 914, 576 P.2d at 974, 145 Cal. Rptr. at 12.

40. Aftcr Comden's interpretation of rule 2-111(A)(4), a client could suffer a more subtle type of larm during the negotiations stage. Suppose plaintiff's attorney is likely to be a witness in a case and that the attorney is to slare $30 \%$ in any settlement and $40 \%$ in any judgment. Negotiations produce a $\$ 40,000$ settlement offer from the defendant. The attorney's experience and sense of the case, however, lead him to conclude that plaintiff has a $90 \%$ chance of prevailing in a judgment of $\$ 100,000$. If the attorney put this before the client, the client might well reject the offer and go to trial. However, after Comden, it is no longer in the attorney's interest that the offer be rejected, simce if the client proceeds to trial, the attoruey runs the risk of disqualification. He will clearly be tempted to withhold information or color the assessment he gives the chent whenever the settlement contingency fee exceeds the hourly fee for time devoted to the case to that point. Thus, Comden may exacerbate tensions already inherent in contingency fee arrangements and generally encourage speculation about improper attorney conduct.

Three arguments might be advanced against the likelihood of Comden's producing these effccts. First, the client has a tort remedy against any attorney who breaches his fiduciary duty to the client if the latter is thercby harmed. However, the subtleties of the attorney's calculations of worth of a case, probability of prevailing, and other intangibles are sucli that a client would face, in all but the most egregious cases, an insurmountable proof problem. Second, Bar sanctions will be applied to attorneys who engage in sucl practices. Since the majority in Comden failed to agree with the dissent's argument that Bar sanctions would be the more appropriate way to deal 
Many clients may prefer delay in the decision to disqualify. ${ }^{41}$ For example, a desire to delay changing counsel may involve calculations about the probability of settlement before trial. A client may also prefer to postpone decision on withdrawal in the hope that discovery will yield evidence stronger than counsel's testimony and thus obviate the attorney-witness problem. The Coundens expressed this preference by their offer to have the firm withdraw after discovery should Greene's testimony remain necessary. The court did not convincingly justify the propriety of the trial court's refusal to respect this preference as to the timing of the disqualification decision. ${ }^{42}$ An immediate and thus premature decision offered the Comdens a protection they did not want. Nor did it protect the image of the Bar, since the shadow of impropriety only arises during trial.

Rather than interpreting rule 2-111(A)(4) to permit preinature disqualification and thereby working a certain and often uimecessary hardship on the client, the court might have determined that rule 2111(A)(4) motions are not ripe until the pretrial conference. At this stage, the court could determine with much greater certainty whether an attorney "ought" to testify. Should the court order withdrawal, trial could be postponed until new counsel is prepared, with only ininimal adverse impact on the parties and judicial efficiency. Where, as in Comden, the plaintiff prefers this approach notwithstanding that it may postpone the granting of the relief he seeks, ${ }^{43}$ only rarely would the defendants or the court have a legitimate interest in objecting.

with the attorney-witness problem, it would be odd for the majority to argue that such sanctions would be sufficient to deal with any confict of interest Comden may have created. Third, attomeys will not engage in such an unethical practice. Even assuming arguendo that this is so, Comden focuses on the appearance of impropriety. And the appearance of impropriety is considerably worse where the public may perceive that attorneys' interests are pitted agaimst their clients' in the settlement process than where the public may perceive no conflict of interest but a mere "unseemliness" in attorneys' testifymg.

41. Where a case is factually or legally simple and new counsel can assimilate it quickly, delay would impose comparatively little burden on the client. Even where the cost in time and money of turning to new counsel would be substantial, a client may nevertheless prefer to rctain existing counsel until trial.

42. The court held that the trial court did not abuse its discretion in concluding that "delaying the decision creates the issue of hardship." 20 Cal. 3d at 914, 576 P.2d at 974, 145 Cal. Rptr. at 12. A trial court apparently has the discretion to postpone decision on disqualification if it concludes that delay would not prejudice the client. While the court stated that the trial court "ordinarily" inust decide "notwithstanding uncertainty," id. at 913-14, 576 P.2d at 974, 145 Cal. Rptr. at 12, it also cited with approval, id., Miller Elec. Constr., Inc. v. Devine Lighting Co., 421 F. Supp. 1020 (W.D. Pa. 1976), where the district court postponed a disqualification dccision until after discovery since no party would be prejudiced. Simply put, the trial judge's contrary conclusion here was but one option within the scope of his discretion.

43. Traditionally, the plaintiff controls the pace of litigation. Unless the pace is unreasonable, the court normally will not substitute its view of effective tactics or the clicn's best interests. The Comden majority apparently believed that rule $2-111(\mathrm{~A})(4)$ justifies alteration of this longstanding deference to the plaintiff's choices and, specifically, permits judicial intervention to force 
III

\section{Application of THE Rule}

After identifying the purposes underlying rule 2-111(A)(4), the court addressed the rule's application and, in particular, the circuinstances requiring attorney withdrawal. Plaintiffs argued that counsel inay continue until it is likely that he should testify, and that until such time, disqualification is preinature. ${ }^{44}$ The court was not persuaded, and refused to leave witlidrawal contingent solely on a determination of likelihood. Pointing to the language of the rule-c"ought to be called as a witness"-and its everyday ineaning, the court held that an attorney inust withdraw wlienever he has a inoral obligation or duty to testify because the testimony will likely be needed to protect the chent's interests. ${ }^{45}$ That duty will depend on such factors as (1) "the significance of the inatters to which he might testify, (2) the weight his testiinony might have in resolving such inatters, and (3) the availability of otlier witnesses or documentary evidence by which these inatters inay be independently established." 46

Disqualification under rule 2-111(A)(4) does not similarly protect the interests of the inoving party. ${ }^{47}$ The advocate's testimony in Comden allegedly threatened plaintiff's case, yet the defendant successfully moved for disqualification. Indeed, the court stated that the rule is not intended to benefit the moving party. ${ }^{48}$ Although the court expressed concern for the professional ethics factors whicll were decisive in conflict of interest cases, ${ }^{49}$ it apparently considered the distinction between

the timing of counsel's pretrial withdrawal. See 20 Cal. $3 d$ at 915,576 P.2d at 975, 145 Cal. Rptr. at 13.

44. Id. at 913,576 P.2d at 973,145 Cal. Rptr. at 11 .

45. Id. See J.P. Foley \& Co. v. Vanderbilt, 523 F.2d 1357, 1359 (2d Cir. 1975).

46. 20 Cal. 3d at 913, 576 P.2d at 973-74, 145 Cal. Rptr. at 11-12.

47. Cf. notes 57-67 and accompanying text infra (detailing prejudice to the client).

48. $20 \mathrm{Cal} .3 \mathrm{~d}$ at $915 \mathrm{n} .3,576 \mathrm{P} .2 \mathrm{~d}$ at $975 \mathrm{n} .3$, 145 Cal. Rptr. at $13 \mathrm{n}$.3. The court thus refused to acknowledge protection of the adversary as a purpose of the advocate-witness rule. Other courts lave similarly discarded arguments that the rule exists to protect the adversary's ability to cross-examine the testifying attorney strenuously or to prevent any disadvantage to his case because of the possibly enhanced credibility of a witness who is also trial counsel. See GreenebaumMountain Mortgage Corp. v. Pioneer Nat'l Title Ins. Co., 421 F. Supp. 1348, 1354 (D. Colo. 1976). See also Sutton, supra note 15, at 480 (fairness to opponents is "[o]ne of the least impressive" reasons for the rule). But see People v. Smith, 13 Cal. App. 3d at 908, 91 Cal. Rptr. at 793 (testifying advocate "would thrust upon his opponent a sticky choice between vigorous cross-examination of his professional colleague and abdication of his own professional responsibility."); ABA CODE OF PROF. RESP., EC 5-9 ("opposing counsel may be handicapped in challenging the credibility of the lawyer when the lawyer also appears as an advocate.").

49. 20 Cal. 3d at 915, 576 P.2d at 975, 145 Cal. Rptr. at 13. The court cited Hull v. Celanese Corp., 513 F.2d 568 (2d Cir. 1975), a leading conflict of interest decision. But see Woods v. Covington County Bank, 537 F.2d 804 (5th Cir. 1976), holding that disqualification would not be warranted unless the court finds not only " $\mathrm{a}$ reasonable possibility of improper professional conduct," but also "that the likelihood of public suspicion or obloquy outweighs the social interests" 
a moving party who seeks to protect himself and one who is not threatened to be immaterial. The court simply asserted that in the conflict between the right to counsel of choice and the need to maintain ethical standards, the latter must prevail.

The dissent, in contrast, ascribed nnore importance to the right to counsel of choice. It questioned the use of disqualification to enforce ethical standards absent a finding of actual or potential "detriment to the opposing party or threat to the . . judicial process."50 Where only the image of the Bar is imvolved, the court's powers do not extend to disqualification.

These are reasonable factors. Their usefulness as a guide to trial courts is diminished, however, because the court did not indicate the level of necessity they must establish to create the duty to testify. It remaims unclear whether the duty exists if the client's chances of success would be only slightly weakened without the testimony or whether a harsher impact should be required. ${ }^{51}$ Because of Comden's procedural posture, the case could be decided without elucidation of the meaning of "necessity." To deny the petition for writ of mandate, the court had only to find that the facts did not compel the conclusion that Greene's testimony would not be necessary at trial. ${ }^{52}$

The supreine court rejected plaintiff' petition for a writ of mandate to compel the trial court to vacate its order. In so doing, the court identified the rule's principal purposes as protection of the client and avoidance of the appearance of impropriety. In the court's view, rule 2$111(\mathrm{~A})(4)$ therefore constituted an ethical standard of professional responsibility that must outweigh a client's right to counsel of choice whenever these principles conflict. Moreover, the court rejected the

served by counsel's continued participation in the case. Id. at 813 n.12. Woods concerned the employment of a former government attorney on a matter handled during his government service, a practice subject to somewhat different and arguably stricter ethical rules. ABA CoDE OF Prof. Resp., DR 9-101(B). See United States v. General Motors Corp., 501 F.2d 639 (2d Cir. 1974).

50. 20 Cal. 3d at 917-18, 576 P.2d at 977, 145 Cal. Rptr. at 15 (Manuel, J., dissenting). See notes 22-24 and accompanying text supra.

51. See J.P. Foley \& Co. v. Vanderbilt, 523 F.2d 1357 (2d Cir. 1975). The court held an attoruey ought to testify when the testimony would be "pivotal" and did not fall within an exception to the ABA advocate-witness rule. But see id. at 1359-60 (Gurfein, J., concurring). Judge Gurfein cautioned that the ABA Code of Professional Responsibility lacked the authority of statute, stating: "When we agree that the Code applies in an equitable manner to a matter before us, we slould not lesitate to enforce it with vigor. When we find an area of uncertainty, however, we must use our judicial process to make our own decision in the interests of justice to all concerned." Id. at 1360.

52. Mandamus cannot control a court's discretion except where, on the facts, that discretion can be exercised in only one way. Harris v. Superior Court, 19 Cal. 3d 786, 799, 567 P.2d 750, 758, 140 Cal. Rptr. 318, 326 (1977); O'Bryan v. Superior Court, 18 Cal. 2d 490, 496-97, 116 P.2d 49, 53 (1941); 5 B. Witkin, CAlifornia Procedure Extraordinary Writs $\$ 879-80$, at 3856-58 (2d ed. 1971). 
plaintiffs' position that "the ability to establish client and witness rapport and to 'form impressions' after legal researeh" was sufficient to satisfy the "distinctive value" exception..$^{53}$ Finally, the court stated that the attorney's services must be "unique" in order to apply the exception; to hold otherwise, argued the court, would allow the exception to swallow the rule. ${ }^{54}$

\section{IV}

EXEMPTIONS FROM RULE 2-111(A)(4)

Rule 2-111(A)(4) contains four exemptions which permit an advocate-witness to remain as trial counsel. The first three are fairly straightforward ${ }^{5 s}$ and the court properly found them inapplicable. Greene's testimony did not relate "solely to an uncontested matter," "to matters of formality," or "to the nature and value of legal services rendered." 56 The ineaning and apphicability of the fourth exemption is inore problematic. Rule 2-111(A)(4)(d) provides that an attorney need not withdraw if this "would work a substantial hardship on the client because of the distinctive value of the lawyer or his firm as counsel in the particular case." 57

A liberal interpretation of "substantial hardship" would have significantly softened the harsh application of the rule that was condoned, if not encouraged, by the court. ${ }^{58}$ To prevent the exception from swallowing the rule, ${ }^{59}$ the court narrowly limited the circumstances that would constitute sufficient hardship. In so doing, the court followed the trend of a number of federal ${ }^{60}$ and state ${ }^{61}$ courts which have strictly construed the ABA's parallel hardship exemption.

The distinctive value of the services of the particular lawyer or his firm is the key to the Comden definition of "substantial hardship."

53. 20 Cal. 3d at 914,576 P.2d at 975,145 Cal. Rptr. at 13.

54. Id.

55. Rule 2-111(A)(4)(a), (b) \& (c), supra note 2.

56. 20 Cal. 3d at 914, 576 P.2d at 974,145 Cal. Rptr. at 12.

57. Rule 2-111(A)(4)(d), supra note 2.

58. See Note, Advocate-Wiiness Rule, supra note 6, at 1375-84, analyzing the strict, compromise, and liberal applications of the lardship exception by various courts. For an example of a simple client-oriented approach in sharp contrast to Comden, see Kenoslua Auto Transp. Corp. v. United States, 206 Ct. Cl. 888 (1975).

59. 20 Cal. 3d at 914,576 P.2d at 975,145 Cal. Rptr. at 13.

60. See, e.g., Draganescu v. First Nat'l Bank of Hollywood, 502 F.2d 550 (5th Cir. 1974); Connell v. Clairol, Inc., 440 F. Supp. 17, 19 (N.D. Ga. 1977) ("any doubt must be resolved in favor of disqualification"); United States $e x$ rel. Sheldon Elec. Co. v. Blackhawk Heating \& Plumbing Co., 423 F. Supp. 486 (S.D.N.Y. 1976).

61. See, e.g., Sinnett v. Albert, 188 Neb. 176, 180, 195 N.W.2d 506, 509 (1972); Perazzelli v. Perazzelli, 147 N.J. Super. 53, 57-60, 370 A.2d 535, 537 (Ch. 1976); Town of Mebane v. Iowa Mut. Ins. Co., 28 N.C. App. 27, 31-32, 220 S.E.2d 623, 626 (1975).

62. $20 \mathrm{Cal} .3 \mathrm{~d}$ at $914,576 \mathrm{P} .2 \mathrm{~d}$ at $974,145 \mathrm{Cal}$. Rptr. at 12. 
high degree of actual burden is a necessary but not sufficient condition for apphication of the exeinption. Therefore, the inconvenience caused by the firm's withdrawal, the loss of established rapport, and the expense of securing new counsel and compensating thein for the duplication of original counsel's preliminary work could not trigger the exemption for the Coindens. According to the court, the cunnulative hardship imposed on thein did not originate in any distinctive value of the firm. ${ }^{63}$ Research, interviewing and preliminary development of trial strategy could not create the requisite distinction. The court recognized that if they could, rule $2-111(\mathrm{~A})(4)$ would be effectively nullified. ${ }^{64}$

A contrasting approach to substantial hardship would einphasize fairness to the chent. ${ }^{65}$ The trial judge would compare the costs to the client with the gains expected froin disqualification. ${ }^{66}$ The effort would focus on safeguarding, to the extent possible, the chent's interests as perceived by the client herself. ${ }^{67}$

\section{$\mathrm{V}$ \\ THE IMPACT OF Comden}

The Comden decision has troubled the California Bar. ${ }^{68}$ First, as the dissent pointed out, "[i]t is coinınonplace for attorneys to participate in the business-legal affairs of their clients." $"$ Many lawyers serve clients primarily as counselors and negotiators outside the fornal adversary system; ${ }^{70}$ only a few exclusively hitigate. Court enforceinent of rule 2-111(A)(4), as in Comden, will undoubtedly disrupt inany prac-

63. Id.

64. Id. at 914,576 P.2d at 975,145 Cal. Rptr. at 13.

65. The ABA Code of Professional Responsibility, EC 5-10, counsels that "[i]n the exceptional situation where it will be manifestly unfair to the client for the lawyer to refuse employment or to withdraw when he will likely be a witness on a contested issue, he may serve as advocate even though he may be a witness."

66. See ABA OpIN., supra note 15 , No. 339. After discussing the disadvantages suffered by the client when trial counsel testifies, the Committee on Ethics and Professional Responsibility acknowledged that "exceptional situations may arise when these disadvantages to the client would clearly be outweighed by the real hardship to the chient of being compelled to retain other counsel."

67. This approach need not mean that the court is bound by the result of the balancing. See Note, Advocate-Witness Rule, supra note 6, at 1379-84.

68. Letters to State Bar of Cahifornia commenting on need to aunend rule 2-111(A)(4), supra note 2, in aftermatl of the Comden decision (State Bar materials on file at the California Law Review).

69. $20 \mathrm{Cal} .3 \mathrm{~d}$ at $916,576 \mathrm{P} .2 \mathrm{~d}$ at $976,145 \mathrm{Cal}$ Rptr. at 14 (Manuel, J., dissenting).

70. See Schwartz, The Professionalism and Accountability of Lawyers, 66 CALIF. L. Rev. 669 (1978), suggesting principles of professional behavior based on the distinction between lawyers acting in advocate and nonadvocate capacities, and arguing that the ABA Code of Professional Responsibility views lawyers primarily as advocates and thus inadequately guides the legal profession in its various nonlitigating roles. 
tices, ${ }^{71}$ as lawyers who serve clients as advisors and negotiators necessarily acquire knowledge that might make useful testimony. Hence the rule has the unintended effect of penalizing what the law should encourage: the utilization of lawyers to promote dispute settlement prior to the commenceinent of litigation. ${ }^{72}$

If litigation proves necessary, disqualification under the rule requires the client to forego the litigating services of the lawyer and firm familiar with the inatter. ${ }^{73}$ Soine clients will lose the assistance of attorneys whio have represented them for years, if that experience lacks the distinctiveness necessary to trigger the hardship exception. Clients will have to attempt to establish a relationship of reciprocal trust and confidence with new counsel, ${ }^{74}$ and presumably bear the expense of new counsel's duplication of much of the origmal counsel's work. ${ }^{75}$ At

71. Levy, Time to Review the Code, 62 A.B.A.J. 225-26 (1976), suggests that the rule's application to the "complex legal-financial inachinery" of conteinporary business will work unnecessary hardships on the chent. See note 57 and accompanying text supra.

72. The dissent recognized the tension between preventive law, which it encourages, and the advocate-witness rule. $20 \mathrm{Cal} .3 \mathrm{~d}$ at 916, 576 P.2d at 976, $145 \mathrm{Cal}$. Rptr. at 14 (Manuel, J., dissenting). See also Greenebaum-Mountain Mortgage Co. v. Pioneer Nat'l Title Ins. Co., 421 F. Supp. 1348, 1352 (D. Colo. 1976).

73. Were the threat of judicial enforcement of rule 2-111(A)(4) to becoine real enough, it could force multiservice law firms to split mto a busmess counseling-and-negotiating firm and a busimess litigation firm. Moreover, the two would have to be truly independent entities and not merely formally separate. See, e.g., Fund of Funds, Inc. v. Arthur Andersen \& Co., 567 F.2d 225 (2d Cir. 1977). If disqualification becomes more frequent, the American system could gradually come to look more like Britain's. Ironically, the latter, with its division of the profession into barristers (trial counsel) and sohicitors (lawyers who handle other legal matters) is "under siege" and "not likely to remain intact for long." N.Y. Tiunes, Mar. 18, 1979, § 1, at 38, col. 1. Lord Goodman, a noted British critic, has said:

I thimk the biggest obstacle to the efficient functioning of our legal system is the absence of a unified profession. If you can have one man conducting the thing, it first creates the right sort of relationship, the right sort of confidence, and it must at the end of the day be more efficient in terms of not transferring a case from hand to hand like a relay race.

Id. at 38, cols. $3-4$.

Alteruatively, a firm might react to the threat of a Comden result by continuing to offer counseling and litigation services but restricting clients to one or the other. For mstance, Loeb \& Loeb might inform the next "Comdens" that they may retain the firm either to negotiate or to litigate. Should prospective clients decide that there is a real cliance of the case going to trial and that they want the firm's litigation services, they should then find "negotiation counsel." It is hard to see how this result-imposing umformly higher transaction costs on potential chents-squares with a decision taken in the name of protecting clients' interests. It is even larder to see low the legal profession's public image is enhanced by forcing clients into what could appear to them as yet another "legal run-around."

74. See Smith v. Superior Court, 68 Cal. 2 d 547, 561, 440 P.2d 65, 74, 68 Cal. Rptr. 1, 10 (1968), where the court relied on the "intimate process of consultation and planning whicl culmmates in a state of trust and confidence between the client and his attorney."

75. One court has recognized that continuing client relationships with a lawyer or a firm prevent the difficulties that would arise if a new attoruey had to familiarize himself with the client and his business each time litigation developed. Greenebaum-Mountain Mortgage Co. v. Pioneer Nat'l Title Ins. Co., 421 F. Supp. 1348, 1352 (D. Colo. 1976). See also Note, Advocate-Witness Rule, supra note 6, at 1384-86. 
best, cooperation between old and new counsel could ameliorate some of these problems. ${ }^{76}$

Second, the Comden decision furnishes little protection against the use of the motion to disquahify as a dilatory or harassing pretrial tactic. ${ }^{77}$ The court recognized that parties frequently wield motions to disqualify as adversarial weapons, ${ }^{78}$ yet it invited any party to a legal proceeding to draw the court's attention to the apphicability of the rule. ${ }^{79}$ The trial judge must assess the apphicability of the rule's ethical diniensions without regard to the tactical motives of the moving party; those inotives are simply irrelevant in deciding the appropriateness of disqualification. ${ }^{80}$

Examples of the burdens imposed on clients and their attorneys by disqualification ordered pursuant to rule 2-111(A)(4) are illustrated in letters to the State Bar of California commenting on the need to amend the rule in light of Comden. (State Bar materials on file at the California Law Review).

76. Close ties between the "witness firm" and the "advocate firm" could trigger the same policy concern for avoidance of the appearance of impropriety that Comden found crucial. Although reciprocal agreements between firms to use each other's services in the event of disqualification are not explicitly covered by rule 2-111(A)(4), such "understandings" could be seen as establishing the sort of "stake" in all members of both firms that in Comden warranted disqualification. The fact that one may consistently be the retaining firm and the other the retained would not seem to alter the conclusion. See Fund of Funds, Ltd. v. Arthur Andersen \& Co., 567 F.2d 225 (2d Cir. 1977).

While it seems unlikely that courts will vigorously pursue the logic of Comden in this manncr, the possibility of such rippling disqualification highlights the major problem of applying conflict of interest considerations to the testifying advocate situation: to do so entitles the moving party to larm the adverse party in the name of protecting the latter's interests. Ironically, the more the client is convenienced in terms of reducing delay and saving money by the cooperation between the disqualified firm and the new one, the more likely would be the disqualification of the new firm under Comden.

77. Courts have recognized that motions to disqualify can be and often are used as an adversarial tactic. See, e.g., International Elecs. Corp. v. Flanzer, 527 F.2d 1288, 1289 (2d Cir. 1975); J.P. Foley \& Co. v. Vanderbilt, 523 F.2d 1357, 1360 (2d Cir. 1975) (Gurfein, J., concurring) (See note 51 supra); Connell v. Clairol, Inc., 440 F. Supp. 17, 18 n.l (N.D. Ga. 1977); United States ex rel. Sheldon Elec. Co. v. Blackhawk Heating \& Plumbing Co., 423 F. Supp. 486, 490 (S.D.N.Y. 1976); Greenebaum-Mountain Mortgage Co. v. Pioneer Nat'l Title Ins. Co., 421 F. Supp. 1348, 1354 (D. Colo. 1976). Cf. Ainpex Corp. v. United States, 211 Ct. Cl. 366 (1976) (en banc); "Disciplinary Rules 5-101 and 5-102, which concern the situation of the law firın's meinber being called as a witness, are primarily for the benefit of clients and courts, not to protect or further the interests of opposing counsel or the opposing party." Id. at 367 .

78. $20 \mathrm{Cal} .3 \mathrm{~d}$ at $915,576 \mathrm{P} .2 \mathrm{~d}$ at $975,145 \mathrm{Cal}$. Rptr. at 13.

79. In the court's words:

We deem it appropriate that the court's attention to the applicability of rule 2-111(A)(4), . . . be invited by a party to the proceedings. However, the rule is not intended to personally benefit such other party, or to aid counsel for such other party. The court is cliarged with taking discretionary action with or without a motion therefor when it is made to appear on considerations affecting an attorney, his client and the public trust, the attorney ought to testify as a witness, and no exception is applicable.

Id. at 915 n.3, 576 P.2d at 975 n.3, 145 Cal. Rptr. at 13 n.3.

80. Some inembers of the California Bar believe a litigant should not have standing to inove for disqualification of opposing counsel under rule 2-111(A)(4). See San Francisco Bar Ethics Committee Letter to State Bar (Nov. 11, 1978) (on file at the California Law Review). They argue 
In response to Comden, the Board of Governors of the California State Bar has tentatively amended rule 2-111(A)(4). ${ }^{81}$ The amendment permits trial counsel to contmue representation knowing that he or a member of his firm ought to testify if the client consents. Counsel must fully advise the client about the possible impact on the case of such representation, and the consent must be im writing.

An amendment to rule 2-111(A)(4) that would permit client consent to the advocate-witness would return to the client the tactical choices conferred on the trial court by the current rule. The client would calculate whether loss of counsel or partial reliance on impeachable testimony most injures her imterests. The amendment would prevent unwanted and ill-timed disruptions of established attorney-client relations and the adversarial abuse of motions to disqualify under the rule. ${ }^{82}$ Perhaps most importantly, permitting client consent would reconcile the conflict between the right to counsel of choice and professional ethics created by the current rule. ${ }^{83}$ The amendment would

that only the client or the court sua sponte should be able to raise the issue. The right, or perhaps the duty, of an attorney to call a court's attention to possible violations of rules of professional conduct evokes issues not easily answered. There can be little doubt, however, that denying opposing counsel standing to move to disqualify under rule 2-111(A)(4) would end their abuse. But it ultimately differs little to the client whether opposing counsel or the court sua sponte invokes the rule to disqualify his counsel. The critical problem is the result: disqualification against the client's will.

81. The tentative amendment was adopted September 11, 1978. As amended the rule states: If upon or after undertaking employment, a member of the State Bar knows or should know that the member or a lawyer in the member's firm ought to be called as a witness on behalf of the member's client in litigation concerning the subject matter of such employment, the ineinber may continue employment only with the written consent of the client given after the client has been fully advised regarding the possible implications of such dual role as to the outcome of the client's cause and has had a reasonable opportunity to seek the advice of independent counsel on the matter. In civil proceedings, the written consent of the client shall be filed with the court not later than the commenceinent of trial. In criminal proceedings, the written consent need not be filed with the court but the member has the duty, before testifying, of satisfying the court that such consent has been obtained. The client's consent need not be obtained in the following circumstances:

(a) if the testimony will relate solely to an uncontested matter; or

(b) if the testimony will relate solely to a matter of formality and there is no reason to believe that substantial evidence will be offered im opposition to the testimony; or

(c) if the testimony will relate solely to the nature and value of legal services rendered in the case by the lawyer or his firm to the client.

(The Board of Governors' resolution and accompanying State Bar material are on file at the California Law Review).

82. Client consent would not affect the power of the court to order disqualification where necessary to ensure justice. For example, in a criminal case in which trial counsel's testimony is likely to be critical, the court might decide that a testifying advocate would confuse a jury and liamper their ability to reacl1 a just verdict. The court need not tolerate serious "disruption [of] the normal balance of judicial machinery," Christensen v. United States, 90 F.2d 152, 155 (7th Cir. 1937), or serious "disturbance to the nice interplay of decisional infiuences," People v. Smith, 13 Cal. App. 3d 897, 908, 91 Cal. Rptr. 786, 794 (3d Dist. 1970).

83. Judge Gurfem expressed a similar concern over the use of disqualification motions as an 
place the client's legitinate interests as determined by the client at the center of professional concern.

Informed client consent could not be uniformly attained without conscientious effort by attorneys and careful supervision by the courts. There is no gainsaying the possibility that a regime of client consent miglit merely open a round of signatures on legal forms and routinized responses to judicial questioning. Nevertheless, since the problems addressed by the rule will not exist in inany cases, particularly where the witness is merely a meinber of trial counsel's law firm, the costs of the current rule appear to outweigh the risks of client consent.

\section{CONCLUSION}

Whetler or not the Bar amendment is adopted, it is a noteworthy response to the Comden apphication of rule 2-111(A)(4). Although the rule exists in part to protect the client, injury to the client, particularly when testimony would be offered by a member of trial counsel's firm, would seein too slight and infrequent in most cases to warrant automatic disqualification. The rule also rests on assumptions about public suspicion and disapproval. Yet even if the public is somewhat skeptical of the advocate-witness, loss of counsel of clioice at the instigation of an adversary inainpulating ethical rules for personal advantage is an excessive price to pay for the inaintenance of the Bar's public image. Indeed, such inaneuvering may be counterproductive to that very end.

Patricia B. Fellner*

adversarial tactic in these words: "As such it demands judicial scrutiny to prevent literalism from possibly overcoming substantial justice to the parties." J.P. Foley \& Co. v. Vanderbilt, 523 F.2d 1357, 1360 (2d Cir. 1975) (Gurfein, J., concurring). He urged courts to consider, but not be bound by, the client's views as a useful factor in determining the need for disqualification. Id.

* A.B. 1970, Smith College, Massachusetts; M.A. 1975, Stanford University; J.D. 1979, Boalt Hall School of Law, University of Cahforuia, Berkeley. 